\title{
Investing in the Future: A Comprehensive Evaluation of Mentorship Networks for Residents
}

Omar F. Khan MD, Alison Walzak MD, Rahim Kachra MD, Theresa J.B. Kline PhD, Fiona M. Clement PhD, Hude Quan PhD, and Aleem M. Bharwani MD

DOI: 10.22374/cjgim.v13i2.228

\author{
About the Authors \\ Dr. Khan is a resident physician in the Medical Oncology residency program at the University of Calgary's Cumming School of Medicine. \\ Dr. Walzak is a clinical assistant professor of medicine at the University of Calgary. \\ Dr. Kachra is a clinical assistant professor of medicine at the University of Calgary. \\ Dr. Kline is a professor emeritus in the Department of Psychology at the University of Calgary. \\ Dr. Clement is an associate professor in the Department of Community Health Sciences and director of the Health Technology Assessment \\ Unit at the University of Calgary. \\ Dr. Quan is a professor at the Department of Community Health Sciences at the University of Calgary. \\ Dr. Bharwani is a clinical assistant professor of medicine at the University of Calgary. \\ Correspondence can be directed to: ambharwa@ucalgary.ca \\ Submitted: September 22, 2017. Accepted: January 2, 2018 Published: June 25, 2018.
}

\begin{abstract}
\section{Background}

Mentorship plays a key career development role in medicine. Traditional mentorship consists of dyadic relationships between mentors and their mentees. However, research favours utilization of mentorship networks involving individuals at multiple levels.
\end{abstract}

\section{Objective}

This study aimed to rigorously evaluate a formalized mentorship network program within a Canadian Internal Medicine residency program from 2012 to 2013.

\section{Methods}

Residents participated in one-on-one semi-structured interviews at baseline and after one year of participation in the mentorship network. Closed-ended surveys assessed affective organizational commitment, self-efficacy, career satisfaction and overall wellness among residents and faculty members. 89 residents and 28 faculty members were invited to participate; 40 residents and 18 faculty members completed the survey after one year.

\section{Results}

Residents perceived mentorship networks to add value across multiple domains, including self-awareness, overall efficiency, and physician wellness. Satisfaction with the program was very high, with $98 \%(n=39 / 40)$ of residents and $89 \%$ of faculty members $(n=16 / 18)$ wanting the program to continue after year one. Male mentors were more likely to report benefits from serving as a mentor than their female counterparts. In contrast to this, female mentees found mentorship more useful than male mentees. 


\section{Conclusions}

Network mentorship is associated with personal and system benefits, though these benefits are difficult to quantify. The network model is feasible and well-received by mentors and mentees. Further research considering both short- and long-term endpoints is required to delineate the true cost-benefit ratio of mentorship programs to both mentors and mentees.

\section{RESUME}

\section{Antécédents}

Le mentorat joue un rôle principal dans le développement d'une carrière en médecine. Le mentorat traditionnel consiste en des relations dyadiques entre les mentors et leurs mentorés. Cependant, la recherche favorise l'utilisation de réseaux de mentorat impliquant des individus à plusieurs niveaux.

\section{Objectif}

Cette étude visait à évaluer rigoureusement un programme formalisé de réseau de mentorat dans le cadre d’un programme de résidence en médecine interne au Canada de 2012 à 2013.

\section{Méthodes}

Les résidents ont participé à des entrevues individuelles semi-structurées au départ et après une année de participation au réseau de mentorat. Les sondages fermés ont évalué l'engagement organisationnel affectif, l'auto-efficacité, la satisfaction professionnelle et le bien-être général chez les résidents et les membres du corps professoral. 89 résidents et 28 membres du corps professoral ont été invités à y participer; 40 résidents et 18 membres du corps professoral ont répondu au sondage après un an.

\section{Résultats}

Les résidents ont perçu les réseaux de mentorat comme une valeur ajoutée dans plusieurs domaines, notamment la connaissance de soi, l'efficacité globale et le mieux-être des médecins. La satisfaction à légard du programme était très élevée: $98 \%(n=39 / 40)$ des résidents et $89 \%$ des membres du corps professoral $(n=16 / 18)$ voulaient que le programme se poursuive après la première année. Les mentors masculins étaient plus susceptibles de rapporter des avantages en tant que mentors que leurs homologues féminins. En revanche, les mentorées féminines ont trouvé le mentorat plus utile que les hommes mentorés.

\section{Conclusions}

Le mentorat en réseau est associé aux avantages personnels et systémiques, bien que ces avantages soient difficiles à quantifier. Le modèle de réseau est réalisable et bien reçu par les mentors et les mentorés. D’autres recherches portant sur des critères d'évaluation à court et à long terme sont nécessaires pour définir le véritable rapport coûts-avantages des programmes de mentorat auprès des mentors et des mentorés.

Mentorship plays a key career development role in medicine. Mentees demonstrate improved productivity, academic success, and career-related decision-making preparedness. ${ }^{1-4}$ Psychosocial benefits, including stress management and enhanced well-being are well established. ${ }^{5,6}$ "Reverse mentorship" confers benefits to the mentor, including increased confidence, personal fulfillment and project assistance. ${ }^{7}$ Organizations benefit through improved recruitment, job performance and employee motivation. ${ }^{8,9}$
Despite this, fewer than half of physicians report having had a mentor at any given time. ${ }^{3}$ Females, members of ethnic minorities and those with career path uncertainty are less likely to have a mentor. ${ }^{2,3}$ Organizational barriers also exist, including time constraints, lack of academic recognition and lack of formal mentorship programs. ${ }^{10,11}$

Traditional mentorship consists of dyadic relationships between mentors and their mentees. However, research favours 
development networks, involving multiple mentors at various levels. ${ }^{5,12}$ Benefits of development networks include the presence of varying skill sets, peer mentorship and a degree of protection from insufficient mentoring. ${ }^{5}$

\section{Methods}

\section{Overview of the Network Mentorship Program and Study Population}

The University of Calgary Internal Medicine Residency Training Program is a three-year curriculum located in a Canadian academic health centre, consisting of 89 residents. The mentorship structure at our institution previously required trainees to individually identify and approach mentors, most often arising from serendipitous interactions and resulting in a dyadic mentormentee relationship. Preliminary surveys revealed the majority of residents did not have a mentor; this disproportionately impacted female residents and those matching to Calgary from elsewhere. The Residency Program Committee (RPC), comprised of both medical residents and faculty members, articulated a need for an improved mentorship structure. Specific areas of need for mentorship identified by the RPC included aspects of instrumental support (clinical development and board exam preparation), psychosocial support (work/life balance) and sponsorship (career and sub-specialization planning).

A formalized mentorship structure was anticipated to equalize resident access to opportunity. We sought a novel mentorship framework to limit implicit bias (subconscious attitudes, stereotypes or preferences impacting behaviour, resulting in gender, ethnic, faith, or other inequities ${ }^{13}$ ) in both the selection and maintenance of serendipitous mentoring relationships. Establishing formally structured mentorship networks achieves this objective.

We constructed mentorship networks by adapting the model of Higgins and Kram ${ }^{12}$ (Figure 1). Networks are influenced by organizational and individual factors, modulated by mentor and mentee interactions at various levels. Each relationship adds to the network's strength and diversity. The network ultimately impacts participants across multiple outputs. Due to the prevalence of physician burnout, ${ }^{14-16}$ physician wellness is a specific mentorship outcome within our framework.

Each network was led by an assigned faculty member and included one to two residents from each program year (see Supplementary Content S1). Each of the 28 networks had a minimum of four semi-structured sessions annually, with flexible member-driven agendas. Suggested topics for meetings (selected based on areas of need identified by the RPC, and based on anticipated benefits of mentorship programs for residents ${ }^{1-4}$ ) typically included board exam preparation, clinical development, career planning, physician wellness and work/life balance. Outside of these meetings, informal interactions occurred in various formats (e.g., in-person, over phone, via text message or e-mail).

Our study included all 89 residents involved in the mentorship program, and all 28 faculty members recruited to lead networks.

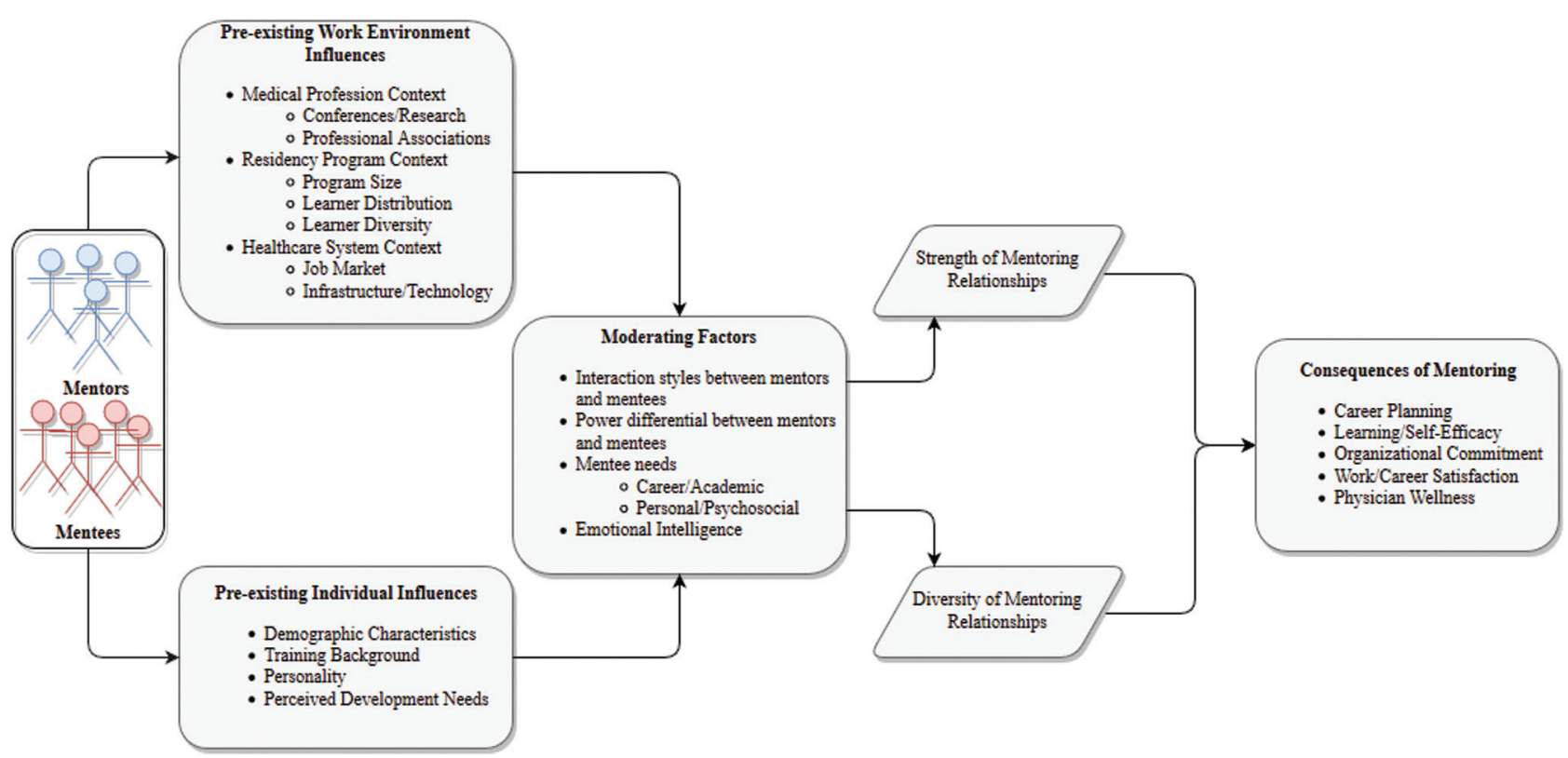

Figure 1. Conceptual framework underlying the creation of a formally structured network mentorship program (adapted from Higgins and Kram ${ }^{12}$ ). 
Involvement in the mentorship program was voluntary for all parties.

\section{Interview Development and Structure}

We invited all residents to participate in recorded one-on-one semi-structured interviews at intake and after one year of participation. Based on the areas of need identified by RPC, residents were asked about their clinical effectiveness, career plan, career/life balance, and mentorship program effectiveness. Residents were also asked about opportunity costs, to help ascertain cost effectiveness of the program. All participants consented to interview recording and transcription.

\section{Survey Development and Structure}

Using existing literature ${ }^{17-19}$ and the semi-structured interviews, we developed a closed-ended survey. This survey included questions regarding career plans, study strategies, work/life balance, and demographics. We utilized five-point Likert-type scaling (with higher scores indicating positive associations) to assess affective organizational commitment (an attitudinal or emotional attachment felt toward an organization ${ }^{18,20}$ ), selfefficacy, career satisfaction and wellness among residents and faculty members. We administered surveys electronically to all participants at baseline and after one year.

\section{Data Analyses}

We used descriptive statistics to characterize demographics and paired sample t-tests to compare baseline to data collected after one year (only including respondents with data from both time points). We used independent sample t-tests to assess differences between genders, and correlations to assess associations between age and item responses for residents and faculty.

Interview transcript content was coded independently by three researchers $(\mathrm{AB}, \mathrm{RK}, \mathrm{AW})$ to extract common themes. Through iterative readings and discussion, we generated a categorical list characterizing perceived strengths, weaknesses and opportunity costs of the mentorship networks. Any identifying information was concealed to ensure participant confidentiality. Additionally, we tracked all labour and operational costs at the organizational level.

Ethics approval was obtained from the Conjoint Health Research Ethics Board at the University of Calgary.

\section{Results}

Semi-structured interviews were conducted with 68 residents at baseline, and with 50 residents after one year. Surveys were sent to all 89 residents and 28 core mentors at baseline; 55 residents and 22 faculty members responded. After one year, surveys were again sent to the same 89 residents and 28 core mentors; 40 residents and 18 faculty members completed the questionnaire. Participant demographics are listed in Table 1. Comparisons between baseline and year one include data from participants who completed surveys and/or interviews at both time points only. Analysis of gender associations revealed no differences between age and level of experience for female compared to male mentors.

\section{Perceptions of Mentorship Networks - Results from Semi-Structured Interviews}

Residents perceived that mentorship networks added value for self-awareness, efficiency, and physician wellness (Table 2). Residents appreciated the diversity, honesty and emotional benefits of their mentorship networks (Figure 2).

Residents were asked during semi-structured interviews about study and career plans (Table 3). After one year of mentorship, more second-year and third-year residents reported having a study plan in place, while fewer reported having a career plan. More first-year residents reported having a career plan after one year.

Table 1. Demographic Characteristics of Faculty and Resident Participants in a Formally Structured Network Mentorship Program

\begin{tabular}{|c|c|c|c|c|}
\hline & \multicolumn{2}{|c|}{ Faculty } & \multicolumn{2}{|c|}{ Residents } \\
\hline Variable & $\begin{array}{l}\text { Baseline } \\
(n=22)\end{array}$ & $\begin{array}{l}\text { Year } 1 \\
(n=18)\end{array}$ & $\begin{array}{l}\text { Baseline } \\
(n=55)\end{array}$ & $\begin{array}{l}\text { Year } 1 \\
(n=40)\end{array}$ \\
\hline $\begin{array}{l}\text { Gender } \\
\text { Male } \\
\text { Female }\end{array}$ & $\begin{array}{l}13(59 \%) \\
9(41 \%)\end{array}$ & $\begin{array}{l}11(61 \%) \\
7(40 \%)\end{array}$ & $\begin{array}{l}29(53 \%) \\
26(47 \%)\end{array}$ & $\begin{array}{l}21(52 \%) \\
19(48 \%)\end{array}$ \\
\hline $\begin{array}{l}\text { Age range: } \\
\text { Under } 30 \\
\text { Over } 30 \\
31-40 \\
41-50 \\
51-60\end{array}$ & $\begin{array}{l}0 \\
22(100 \%) \\
8(36 \%) \\
12(55 \%) \\
2(9 \%)\end{array}$ & $\begin{array}{l}0 \\
18(100 \%) \\
6(33 \%) \\
11(61 \%) \\
1(6 \%)\end{array}$ & $\begin{array}{l}40(73 \%) \\
15(27 \%)\end{array}$ & $\begin{array}{l}29 \\
(72.5 \%) \\
11 \\
(27.5 \%)\end{array}$ \\
\hline $\begin{array}{l}\text { Residency Year: } \\
\text { First } \\
\text { Second or Later }\end{array}$ & - & - & $\begin{array}{l}23(42 \%) \\
32(58 \%)\end{array}$ & $\begin{array}{l}15 \\
(37.5 \%) \\
25 \\
(62.5 \%)\end{array}$ \\
\hline $\begin{array}{l}\text { Years on Faculty, } \\
\text { Mean (SD) }\end{array}$ & $8.0(5.3)$ & $9.4(5.7)$ & - & - \\
\hline $\begin{array}{l}\text { Years as Mentor, } \\
\text { Mean (SD) }\end{array}$ & $3.2(3.5)$ & $3.7(5.2)$ & - & - \\
\hline
\end{tabular}

$\mathrm{SD}=$ standard deviation. 


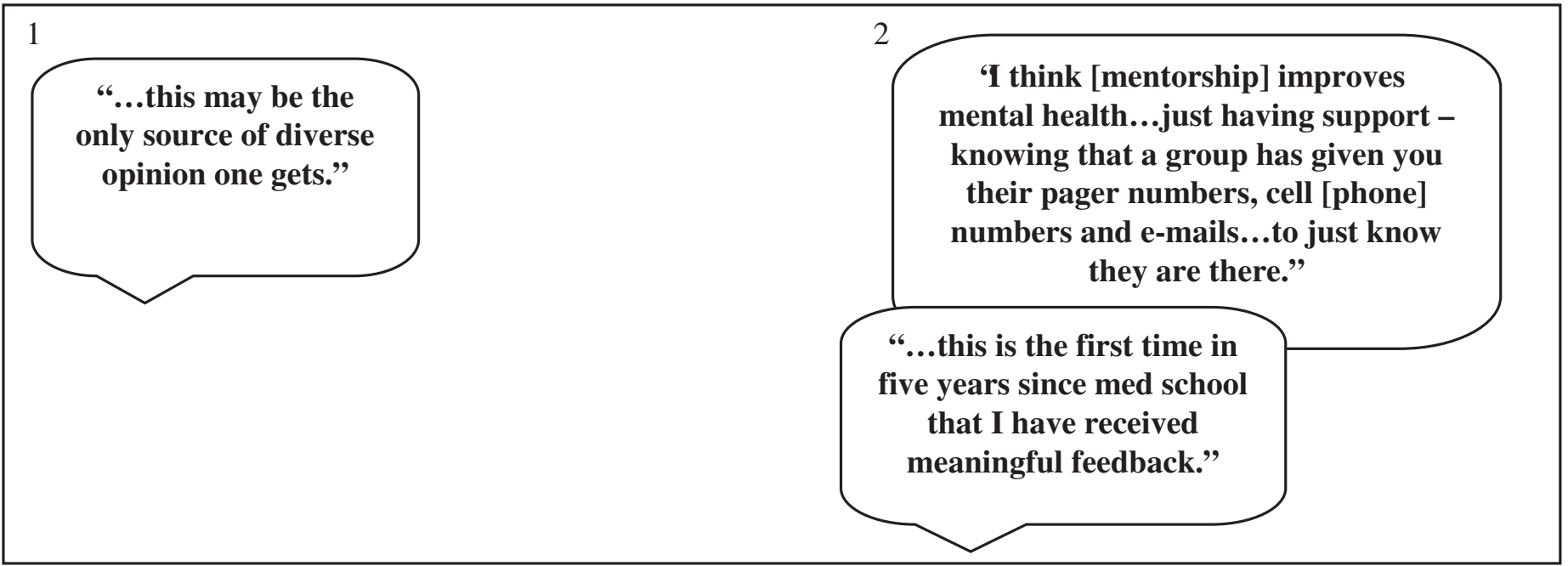

Figure 2. Resident perceptions regarding feedback received from mentorship groups.

Table 2. Qualitative Benefits and Pitfalls Reported by Residents $(N=50)$ Participating in a Formal Network Mentorship Program

\begin{tabular}{|c|c|c|c|}
\hline \multicolumn{2}{|r|}{ Perceived Benefits } & \multicolumn{2}{|r|}{ Perceived Pitfalls } \\
\hline \multirow{4}{*}{ Self-Awareness } & Provides a means to structure reflection & \multirow{2}{*}{ Mentor Matching } & $\begin{array}{l}\text { Assigned mentors may not align with career } \\
\text { interest area }\end{array}$ \\
\hline & Supports honest, open feedback & & $\begin{array}{l}\text { Diminished opportunity for peer mentorship within } \\
\text { a given residency year }\end{array}$ \\
\hline & Diversifies perspectives & \multirow{2}{*}{ Mentor Training } & Lack of leadership skill development \\
\hline & Explores important but non-urgent issues & & Lack of guidance surrounding physician wellness \\
\hline \multirow{3}{*}{$\begin{array}{l}\text { Workplace } \\
\text { Efficiency and } \\
\text { Relationships }\end{array}$} & Hastens networking & & \\
\hline & Improves strategic planning & & \\
\hline & Flattens organizational hierarchy & & \\
\hline \multirow{6}{*}{$\begin{array}{l}\text { Wellness and } \\
\text { Balance }\end{array}$} & $\begin{array}{l}\text { Provides immediate and ongoing individualized } \\
\text { guidance }\end{array}$ & & \\
\hline & Supports unknown future challenges & & \\
\hline & Reduces stress & & \\
\hline & Improves resident relationships & & \\
\hline & Allows for safe expression of vulnerability & & \\
\hline & Humanizes trainees and faculty & & \\
\hline
\end{tabular}


Table 3. Self-Reported (Via Semi-Structured Interviews) Proportions of Residents Having Study and/or Career Plans in Place While Participating in a Network Mentorship Program (Data For All Interview Respondents At Each Time Point Shown)

\begin{tabular}{|c|c|c|c|c|}
\hline \multirow[b]{2}{*}{$\begin{array}{c}\text { Residency year } \\
\text { (at baseline) }\end{array}$} & \multicolumn{2}{|c|}{ Study plan in place } & \multicolumn{2}{|c|}{ Career plan in place } \\
\hline & $\begin{array}{l}\text { Baseline } \\
(n=65)\end{array}$ & $\begin{array}{l}\text { After one year } \\
\quad(n=40)\end{array}$ & $\begin{array}{l}\text { Baseline } \\
(n=65)\end{array}$ & $\begin{array}{l}\text { After one year } \\
\qquad(n=40)\end{array}$ \\
\hline First-year & $0.0 \%(0 / 29)$ & $0.0 \%(0 / 10)$ & $10.3 \%(3 / 29)$ & $40.0 \%(4 / 10)$ \\
\hline Second-year & $42.1 \%(8 / 19)$ & $73.3 \%(11 / 15)$ & $63.2 \%(12 / 19)$ & $46.7 \%(7 / 15)$ \\
\hline Third-year & $29.4 \%(5 / 17)$ & $86.7 \%(13 / 15)$ & $82.3 \%(14 / 17)$ & $40.0 \%(6 / 15)$ \\
\hline
\end{tabular}

\section{Perceptions of Mentorship Networks - Results from Year- One Survey}

Mentorship network satisfaction was high, with nearly all residents $(98 \%, \mathrm{n}=39 / 40)$ and faculty members $(89 \%, \mathrm{n}=16 / 18)$ wanting the program to continue after year one.

Faculty surveys revealed younger mentors found mentorship useful to support residents $(r=-0.52, \mathrm{p}=0.03)$ and train high-quality clinicians, more so than older mentors $(r=-0.48$, $\mathrm{p}=0.04)$; they also valued reverse mentorship more to support their professional growth $(r=-0.50, \mathrm{p}=0.03)$. Male mentors felt better prepared to be a mentor $(t=3.76, \mathrm{p}=0.002)$, and reported higher affective organizational commitment than female mentors $(t=2.40, \mathrm{p}=0.03)$. Male mentors were also more likely to report enhanced mentorship skills due to peer mentorship $(t=2.30, \mathrm{p}=0.04)$ and to find mentorship useful for career planning $(t=3.61, \mathrm{p}=0.002)$. Finally, male mentors met more frequently with their networks than females $(t=2.63, \mathrm{p}=0.02)$.

In contrast to this, female mentees were more likely than males to rate their mentorship network as useful $(t=2.36$, $\mathrm{p}=0.02)$, accessible $(t=3.19, \mathrm{p}=0.003)$, supportive $(t=2.42$, $\mathrm{p}=0.02)$, and constructive $(t=3.48, \mathrm{p}=0.001)$. Female mentees were more likely than males to find mentorship helpful to achieve administrative $(t=2.03, \mathrm{p}=0.05)$, teaching $(t=2.61, \mathrm{p}=0.01)$, work/life balance $(t=2.09 \mathrm{p}=0.04)$ and research $(t=2.91$, $\mathrm{p}=0.006$ ) goals. Supplementary Table 1 lists all t-tests for gender differences and mentorship perceptions.

\section{Pre-post Evaluation of the Network Mentorship Program by Faculty and Residents}

There were no significant differences between faculty survey responses at baseline vs year one. However, after one year, residents scored higher on the Affective Commitment Scale ${ }^{18}$ $(t=-2.67, \mathrm{p}=0.02)$, and felt increased support for growth and development $(t=-2.18, \mathrm{p}=0.04)$. However, residents were less certain they could accomplish their goals $(t=2.18, \mathrm{p}=0.04)$ and less likely to feel they were on a definite career path $(t=2.36$, $\mathrm{p}=0.03$ ). Additionally, residents were less interested in full-time clinical work $(\boldsymbol{t}=2.45, \mathrm{p}=0.03)$. Supplementary Table 2 lists full resident responses.

\section{Network Mentorship Program Costs}

Mentorship program costs included mentor training and compensation, and program administrative costs. Monetary compensation for attending physicians was calculated based on their time commitments multiplied by the Alternative Remuneration Program physician rate (\$150/hour). Resident opportunity costs were valued based on their time commitments multiplied by the average hourly wage earned ( $\$ 29.16 /$ hour). Program administrative costs included costs for supplies, in addition to the administrative support time commitment multiplied by their hourly wage ( $\$ 30 /$ hour). Time commitments for residents and attending physicians were self-reported, and administrative time was logged on time sheets. Mentor training consisted of eight hours of workshops, with speaker wages of $\$ 1200$ (all costs in Canadian dollars). Mentor time commitments (approximately 20 hours per mentor) cost $\$ 84000$, while resident time commitments were valued at $\$ 21000$. Program administrative costs totalled approximately $\$ 1000$. The cumulative annual cost for the mentorship program was approximately $\$ 106000$ - an annual per-resident cost of approximately $\$ 1191$.

\section{Discussion}

This study evaluated formalized network mentorship in an academic residency program. Residents and faculty strongly supported continuing our mentorship networks. Based on Haji et al. ${ }^{21}$ we identified both expected and unexpected processes and outcomes to evaluate our mentorship networks. 


\section{Process Evaluation}

Mentorship networks created equal opportunity for mentorship to all residents. In addition, mentorship networks were logistically and financially feasible. While tangible costs are easily recorded, opportunity costs to mentors and mentees are not easily quantifiable. Benefits (e.g., affective organizational commitment) are underrepresented because they accrue over time periods outside of the scope of this evaluation. Physician attrition costs are significant, with an average cost of over $\$ 400,000$ to replace a single faculty member in an academic institution ${ }^{22}$; hiring and training costs for new faculty members ranged between $\$ 150,000$ and $\$ 185,000$ in one American academic centre. ${ }^{23}$ In Canada, monetary recruitment costs are likely lower. More research, however, is needed to explore the indirect costs on busy Canadian clinicians who may incur higher workloads and increased burnout from inefficient recruitment and retention. Given such significant costs, even a modest improvement in physician retention due to mentorship would likely render the program cost-effective.

Surprisingly, female mentors met their groups less frequently and felt less prepared than male mentors, despite having similar ages and levels of experience. This is concerning, given the important gender perspective female mentors provide, and literature suggesting females are less likely to be mentors ${ }^{24}$ or to seek out a mentor. ${ }^{3,25,26}$ Costs and time pressures associated with mentoring others may impact females more than males. ${ }^{27,28}$ Fewer females receive mentorship during their career development, potentially impacting their future participation in mentorship programs. Finally, the relative dearth of women in leadership positions presents a potentially circular challenge - female mentees lack female leaders to seek as role model ${ }^{5,6}$; this lack of mentorship may in turn lead to fewer leadership opportunities for the mentee. One benefit of our formal network mentorship structure is that all residents - regardless of gender - have a mentor, which over time may result in more female mentors arising organically through the program. The challenge of achieving gender equity among mentors is clear and represents broader societal cultural challenges, necessitating further research exploring opportunity costs for female mentors, and potential organizational supports for female mentors. ${ }^{29}$

\section{Outcomes Evaluation}

Benefits of mentorship networks for residents surround enhancement of self-awareness skills and relationships. Residents perceived improved affective organizational commitment and self-efficacy after one year of mentorship. While clinical rotation and exam preparation improved, no impact on career satisfaction or work/life balance occurred. Residents felt mentors were not adequately trained to advise on wellness and work/life balance goals. Further mentor development should include formalized training on achieving work/life balance; however, determining optimal mentor development strategies requires further research.

Residents appreciated feedback from their network, but paradoxically felt less able to meet their goals. Perhaps mentors overwhelmed residents with information regarding career path options or provided insight into job market competitiveness in career paths residents were considering. This explanation is supported by resident feedback indicating mentorship networks provided a significant (and potentially only) source of diversity in career planning. However, increased diversity might amplify "background noise," further clouding the "signal" residents are seeking. Importantly, the announcement of an unanticipated and subsequently well-publicized hiring freeze at our university shortly before delivery of the year one survey may explain declines in resident perceptions surrounding achieving their goals and career planning.

Gender also played an important role for mentees, as females had a better image of the mentorship networks than males. This is consistent with data suggesting females are more likely than males to engage in cooperative behaviour ${ }^{30}$ and collaborative work. ${ }^{31}$ Mentoring may therefore better suit the work and learning style of women. ${ }^{32}$

\section{Evaluation Standards and Mentorship Network Modifications}

We applied program evaluation standards ${ }^{33}$ to our mentorship networks (Supplementary Table 3). Utility, propriety and feasibility standards were upheld via explicit involvement of all stakeholder groups throughout the design, implementation and evaluation process. Costs were tracked at individual and organizational levels. Accuracy standards were addressed through collection of qualitative and quantitative data at multiple time points.

The evaluation helped guide changes within the mentorship networks and the residency program as a whole, including a renewed program-wide focus on physician wellness. "Conversation starters" - broad questions or statements aimed at facilitating discussions on high-yield topics - were disseminated prior to mentorship network meetings. Potential improvements to our implementation and evaluation process include better documenting and distributing explicit rationales for program structure modifications and conducting external meta-evaluations of processes and outcomes.

This study demonstrates the need for more robust short-term and long-term analysis of individual and system-level benefits and costs of mentorship. A clear understanding of potential gains and pitfalls of mentorship networks is critical to focus the development of mentor training and an evaluation curriculum. 


\section{Conclusions}

Do the benefits of mentorship networks justify the monetary and opportunity costs for participants? This study suggests mentorship is associated with a mix of personal and system benefits, though they are difficult to quantify. Mentorship networks may also provide other intangible benefits, as an overwhelming majority of residents and faculty favoured continuing the program. Further research considering both short- and long-term endpoints is required to delineate the true costs and benefits of mentorship programs.

\section{Sources of Funding}

Dr. Clement was supported by a Harkness fellowship in Health care policy and practice.

\section{Conflicts of Interest/Competing Interests}

The authors declare they have no conflicts of interest or competing interests.

\section{Prior Presentations}

Portions of this study were presented at the International Conference on Residency Education in Calgary, Canada (September 2013); at the Association for Medical Education in Europe in Prague, Czech Republic (August 2013); and at the Canadian Society for Internal Medicine in Quebec City, Canada (October 2012).

\section{Acknowledgments}

The authors wish to thank the W21C initiative (http://w21c. org) for their contributions with regards to logistics, space and in-kind resources.

\section{References}

1. Sambunjak D, Straus SE, Marusic A. Mentoring in academic medicine: A systematic review. JAMA 2006;296(9):1103-15.

2. Ramanan RA, Taylor WC, Davis RB, Phillips RS. Mentoring matters. mentoring and career preparation in internal medicine residency training. J Gen Intern Med 2006;21(4):340-45.

3. Stamm M, Buddeberg-Fischer B. The impact of mentoring during postgraduate training on doctors' career success. Med Educ 2011;45(5):488-96.

4. Frei E, Stamm M, Buddeberg-Fischer B. Mentoring programs for medical students--a review of the PubMed literature 2000-2008. BMC Med Educ 2010;10:32-6920-10-32.

5. DeCastro R, Sambuco D, Ubel PA, Stewart A, Jagsi R. Mentor networks in academic medicine: Moving beyond a dyadic conception of mentoring for junior faculty researchers. Acad Med 2013;88(4):488-96.

6. Steven A, Oxley J, Fleming WG. Mentoring for NHS doctors: Perceived benefits across the personal-professional interface. J R Soc Med 2008;101(11):552-57.

7. Taherian K, Shekarchian M. Mentoring for doctors. do its benefits outweigh its disadvantages? Med Teach 2008;30(4):e95-9.

8. Allen TD, O'Brien KE. Formal mentoring programs and organizational attraction. Hum Res Dev Quart 2006;17(1):43-58.
9. Wilson JA, Elman NS. Organizational benefits of mentoring. The Executive 1990;4(4):88.

10. Ehrich LC, Hansford B, Tennent L. Formal mentoring programs in education and other professions: A review of the literature. Educ Admin Quart 2004;40(4):518-40.

11. Straus SE, Chatur F, Taylor M. Issues in the mentor-mentee relationship in academic medicine: A qualitative study. Acad Med 2009;84(1):135-39.

12. Higgins MC, Kram KE. Reconceptualizing mentoring at work: A developmental network perspective. Academy of Management. Acad Manag Rev 2001;26(2):264-88.

13. Levine RB, Mechaber HF, Reddy ST, Cayea D, Harrison RA. "A good career choice for women": Female medical students' mentoring experiences: A multi-institutional qualitative study. Acad Med 2013;88(4):527-34.

14. Dewa CS, Loong D, Bonato S, Thanh NX, Jacobs P. How does burnout affect physician productivity? A systematic literature review. BMC health services research 2014;14(1): 1

15. Dyrbye LN, West CP, Satele D, et al. Burnout among U.S. medical students, residents, and early career physicians relative to the general U.S. population. Acad Med 2014;89(3):443-51.

16. Shanafelt TD, Mungo M, Schmitgen J, et al. Longitudinal study evaluating the association between physician burnout and changes in professional work effort. 2016;91(4):422-31.

17. Lounsbury JW, Park S, Sundstrom E, Williamson JM, Pemberton AE. Personality, career satisfaction, and life satisfaction: Test of a directional model. J Career Assess 2004;12(4):395-406.

18. Meyer JP, Allen NJ, Smith CA. Commitment to organizations and occupations: Extension and test of a three-component conceptualization. J Appl Psychol 1993;78(4):538-51.

19. Scholz U, Dona BG, Sud S, Schwarzer R. Is general self-efficacy a universal construct? *: Psychometric findings from 25 countries. Eur J Psychol Assess 2002(Special Section on Program Evaluation 18(3):242-51.

20. Meyer JP, Allen NJ. A three-component conceptualization of organizational commitment. Human resource management review. 1991;1(1):61-89.

21. Haji F, Morin M, Parker K. Rethinking programme evaluation in health professions education: Beyond 'did it work?'. Med Educ 2013;47(4):342-351.

22. Schloss EP, Flanagan DM, Culler CL, Wright AL. Some hidden costs of faculty turnover in clinical departments in one academic medical center. Acad Med 2009;84(1):32-36.

23. Waldman JD, Kelly F, Arora S, Smith HL. The shocking cost of turnover in health care. Health Care Manage Rev 2004;29(1):2-7.

24. O'Brien KE, Biga A, Kessler SR, Allen TD. A meta-analytic investigation of gender differences in mentoring. J Manage 2010;36(2):537-54.

25. Ragins BR. Barriers to mentoring: The female manager's dilemma. Hum Rel 1989;42(1):1-22.

26. Ragins BR, Cotton JL. Easier said than done: Gender differences in perceived barriers to gaining a mentor. Acad Manage J 1991;34(4):939-51.

27. Ragins BR, Cotton JL. Gender and willingness to mentor in organizations. J Manage 1993;19(1):97-111.

28. Ragins BR, Scandura TA. Burden or blessing? expected costs and benefits of being a mentor. J Organ Behav 1999;20(4):493-509.

29. Strong EA, De Castro R, Sambuco D, et al. Work-Life balance in academic medicine: Narratives of physician-researchers and their mentors. J Gen Int Med 2013;28(12):1596-03.

30. Molina JA, Gimenez-Nadal JI, Cuesta JA, et al Gender differences in cooperation: Experimental evidence on high school students. PLoS One 2013;8(12):e83700.

31. Stump GS, Hilpert JC, Husman J, Chung W, Kim W. Collaborative learning in engineering students: Gender and achievement. J Eng Educ 2011;100(3):475-97.

32. Philbin M, Meier E, Huffman S, Boverie P. A survey of gender and learning styles. Sex Roles 1995;32(7-8):485-94.

33. Yarbrough DB, Shulha LM, Hopson RK, Caruthers FA. The program Evaluation Standards: A Guide for Evaluators and Evaluation Users. Sage Publications; 2010. 


\section{Supplemental Contact}

1. Supplemental Content S1: Faculty member selection process and logistic organization of mentorship networks in a formally structured mentorship program. Format: Text Document

2. Supplemental Table 1: T-tests of differences between gender and statements about mentorship after one year of participation in a formally structured network mentorship program.

Format: Text Document (Table)

3. Supplemental Table 2: Resident responses to quantitative survey questions at baseline and after one year of participation in a formally structured network mentorship program (only residents with survey responses both at baseline and after year one included). Format: Text Document (Table)

4. Supplemental Table 3: Application of the Joint Committee on Standards for Educational Evaluation (JCSEE) Program Evaluation Standards to a formally structured network mentorship program.

Format: Text Document (Table)

\section{Supplemental Content S1}

Faculty member selection process and logistic organization of mentorship networks in a formally structured mentorship program.

\section{Faculty Member Selection Process}

A subset of the Residency Program Committee members selected faculty mentors from a faculty list, with candidates ranked based on subjective scores of each member's reputation for excellence in research, education, clinical care and emotional intelligence. Faculty members excelling in emotional intelligence and at least two other areas were included in a final list. This list was reviewed by Division Heads of the Department of Medicine for additional quality control. Our final list included 40 faculty members. The top 30 of these candidates were invited to participate in exploratory discussions of the network mentorship model. Twenty-eight of the candidates agreed to participate in the program.

\section{Mentorship Network Logistic Organization}

Once faculty members were identified, residents within each residency year were randomly divided among the 28 mentorship networks. A random assignment process was selected to encourage formation of new connections, and to increase the overall diversity of the mentorship networks.

Prior to the beginning of each academic year, four meeting dates were agreed upon by the RPC and chief medical residents. On each of these four dates, a two-hour window of protected time for mentorship was built into the academic half-day curriculum, though each mentorship network was free to select their own meeting times and locations based on their individual schedules. Each year, incoming first-year residents were randomly divided to join one of the networks, allowing each network to grow and evolve over time.

All faculty members involved with the program met yearly to share ideas, successes and challenges. Residents within each program year also met, to disseminate and scale the best ideas throughout each mentorship network.

Supplemental Table 1. T-tests of differences between gender and statements about mentorship, in a survey of faculty members ( $\mathrm{n}=18$ ) and residents $(n=40)$ after one year of participation in a formally structured network mentorship program. italicized statements were significantly different.

\begin{tabular}{|l|c|c|c|c|}
\hline \multicolumn{1}{|c|}{ Statement } & \multicolumn{1}{|c|}{$\begin{array}{c}\text { Mean (SD) } \\
\text { for Males }\end{array}$} & $\begin{array}{c}\text { Mean (SD) for } \\
\text { Females }\end{array}$ & t-value \\
\hline \multicolumn{2}{|c|}{ Faculty Members (Mentors) } \\
\hline I have a high degree of interest in being a mentor & $4.64(0.50)$ & $4.14(0.69)$ & 1.76 \\
\hline I enjoy being a core mentor & $4.64(0.50)$ & $3.86(1.07)$ & 2.10 \\
\hline I have the time to be a mentor & $3.27(1.19)$ & $2.71(0.76)$ & 1.10 \\
\hline Mentorship is a useful tool to support residents & $4.55(0.52)$ & $4.14(0.69)$ & 0.10 \\
\hline I feel adequately prepared to act as a mentor & $3.82(0.75)$ & $2.43(0.79)$ & 0.29 \\
\hline
\end{tabular}


Kahn et al

\begin{tabular}{|c|c|c|c|c|}
\hline Reverse mentorship contributes to my own professional growth & $4.09(0.70)$ & $3.43(1.27)$ & 1.43 & 0.17 \\
\hline $\begin{array}{l}\text { Peer mentorship sessions (including workshops) enhance } \\
\text { mentorship skills }\end{array}$ & $4.18(0.75)$ & $3.43(0.53)$ & 2.30 & $0.04^{*}$ \\
\hline Mentorship is a useful tool to be better clinicians & $4.36(0.67)$ & $3.57(1.13)$ & 1.87 & 0.08 \\
\hline Mentorship is a useful tool to prepare for certifying examinations & $4.18(0.87)$ & $3.71(1.11)$ & 1.00 & 0.33 \\
\hline Mentorship is a useful tool to career plan & $5.00(0.00)$ & $4.43(0.53)$ & 3.61 & $0.002 *$ \\
\hline Mentorship is useful to promote wellness and career/life balance & $4.82(0.40)$ & $4.14(1.07)$ & 1.92 & 0.07 \\
\hline Mentorship is a useful tool to prepare for fellowship & $4.18(0.75)$ & $3.14(1.21)$ & 2.26 & $0.04^{*}$ \\
\hline $\begin{array}{l}\text { Mentorship is useful to support residents and train high-quality } \\
\text { clinicians }\end{array}$ & $4.27(0.90)$ & $3.29(1.38)$ & 1.84 & $0.03 *$ \\
\hline Affective Organizational Commitment & $3.94(0.64)$ & $3.20(0.60)$ & 2.40 & $0.03 *$ \\
\hline Frequency of mentor group meetings per year & $3.82(0.98)$ & $2.57(0.98)$ & 2.63 & $0.02 *$ \\
\hline \multicolumn{5}{|c|}{ Residents (Mentees) } \\
\hline $\begin{array}{l}\text { My mentorship group is constructive and provides useful } \\
\text { critiques }\end{array}$ & $2.95(1.72)$ & $4.23(0.69)$ & 3.48 & 0.001 * \\
\hline My mentorship group is accessible & $3.38(1.53)$ & $4.58(0.61)$ & 3.19 & $0.003^{*}$ \\
\hline $\begin{array}{l}\text { I feel I have access to the appropriate network to accomplish my } \\
\text { clinical goals }\end{array}$ & $3.86(0.73)$ & $4.21(0.54)$ & 1.74 & 0.09 \\
\hline $\begin{array}{l}\text { I feel I have access to the appropriate network to accomplish } \\
\text { my research goals }\end{array}$ & $3.29(1.01)$ & $4.11(0.74)$ & 2.91 & $0.006^{*}$ \\
\hline $\begin{array}{l}\text { I feel I have access to the appropriate network to accomplish } \\
\text { my career/life balance and wellness goals }\end{array}$ & $3.29(1.01)$ & $3.89(0.81)$ & 2.09 & $0.04^{*}$ \\
\hline $\begin{array}{l}\text { I feel I have access to the appropriate network to accomplish } \\
\text { my teaching goals }\end{array}$ & $3.33(0.86)$ & $4.00(0.75)$ & 2.61 & $0.01 *$ \\
\hline $\begin{array}{l}\text { I feel I have access to the appropriate network to accomplish } \\
\text { my administrative goals (leadership, program development, } \\
\text { committee work, etc.) }\end{array}$ & $3.38(0.74)$ & $3.84(0.69)$ & 2.03 & $0.05^{\star}$ \\
\hline $\begin{array}{l}\text { Mentorship challenges me to extend my abilities (e.g. risk } \\
\text { taking, trying a new professional activity, etc.) }\end{array}$ & $2.52(1.47)$ & $3.68(1.06)$ & 2.84 & $0.007^{*}$ \\
\hline My mentorship group is supportive & $3.71(1.55)$ & $4.63(0.60)$ & 2.42 & $0.02 *$ \\
\hline I believe mentorship is a useful tool & $4.38(0.50)$ & $4.74(0.45)$ & 2.36 & $0.02 *$ \\
\hline
\end{tabular}


Supplemental Table 2. Resident $(n=20)$ responses to quantitative survey questions at baseline and after one year of participation in a formally structured network mentorship program (only residents with survey responses both at baseline and after year one included). italicized statements were significantly different.

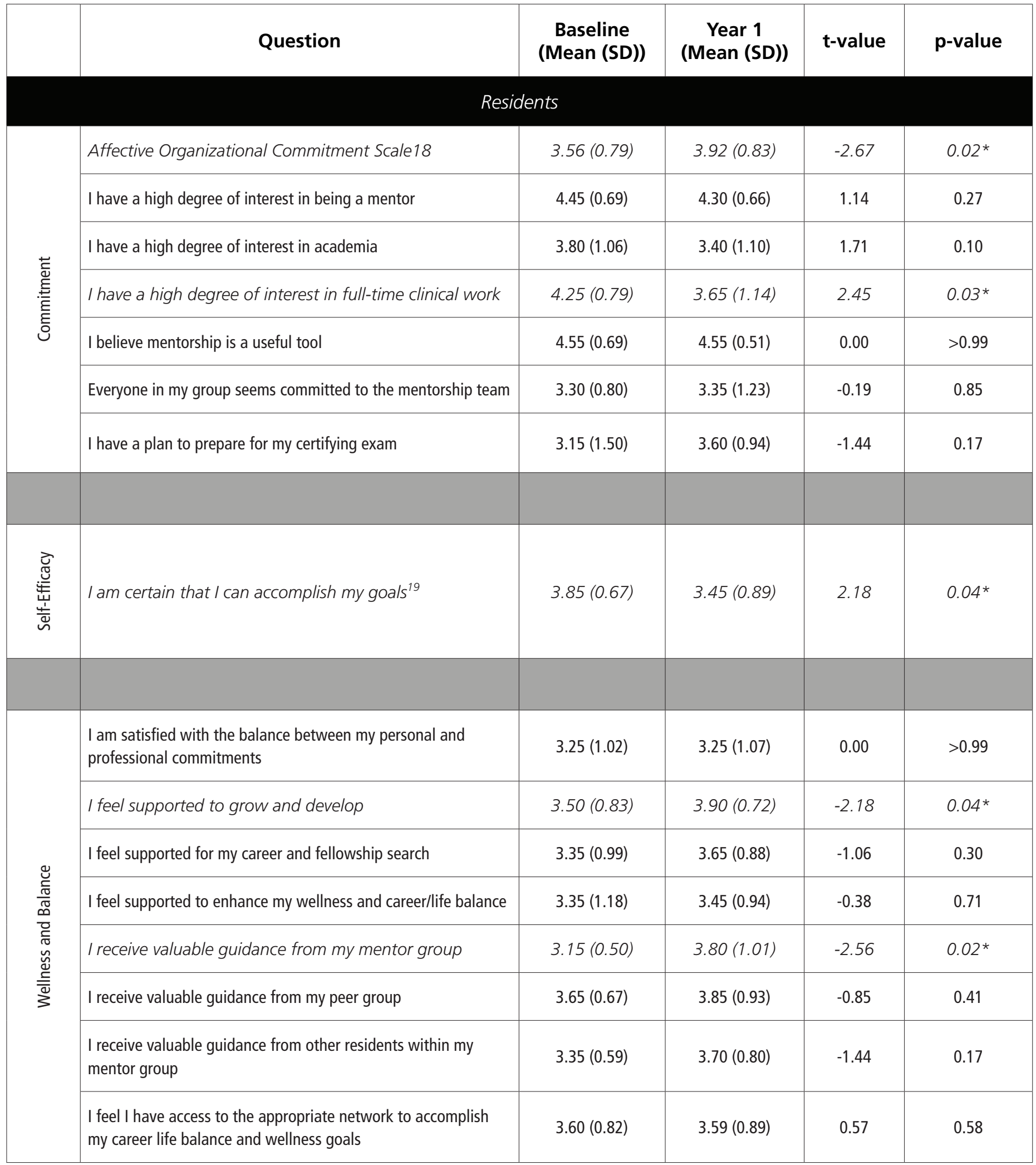




\begin{tabular}{|c|c|c|c|c|c|}
\hline \multirow{6}{*}{ 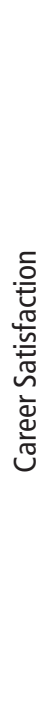 } & $\begin{array}{l}\text { I feel that I am on a definite career path which leads } \\
\text { somewhere }{ }^{17}\end{array}$ & $3.90(0.85)$ & $3.40(0.94)$ & 2.36 & $0.03 *$ \\
\hline & $\begin{array}{l}\text { I am very satisfied with the way my career has progressed so } \\
\operatorname{far}^{17}\end{array}$ & $3.95(0.76)$ & $3.80(0.61)$ & 1.14 & 0.27 \\
\hline & $\begin{array}{l}\text { I feel I have access to the appropriate network to accomplish } \\
\text { my research goals }\end{array}$ & $3.55(0.89)$ & $3.65(0.88)$ & -0.40 & 0.69 \\
\hline & $\begin{array}{l}\text { I feel I have access to the appropriate network to accomplish } \\
\text { my administration goals }\end{array}$ & $3.35(0.67)$ & $3.50(0.76)$ & -0.77 & 0.45 \\
\hline & $\begin{array}{l}\text { I feel I have access to the appropriate network to accomplish } \\
\text { my teaching goals }\end{array}$ & $3.55(0.69)$ & $3.55(0.76)$ & 0.00 & $>0.99$ \\
\hline & $\begin{array}{l}\text { I feel I have access to the appropriate network to accomplish } \\
\text { my clinical goals }\end{array}$ & $3.95(0.69)$ & $3.95(0.69)$ & 0.00 & $>0.99$ \\
\hline
\end{tabular}

Supplementary Table 3. Application of the Joint Committee on Standards for Educational Evaluation (JCSEE) Program Evaluation Standards to a network mentorship program at the University of Calgary.

\section{JCSEE Standard}

Application to Network Mentorship Program Evaluation

Utility Standards

U1. Evaluator Credibility

The evaluation team included expertise in the fields of internal medicine, psychology, public health, health economics and health technology assessment.

U2. Attention to Stakeholders

All aspects of the mentorship network program, from design through to evaluation, included all identified stakeholders (attending physicians, program administration, department and division heads, resident physicians, administrative staff, mentors and mentees

U3. Negotiated Purposes

The purposes of all surveys and interviews (for research as well as quality improvement) were determined by stakeholder groups prior to implementation.

U4. Explicit Values

Surveys and semi-structured interviews were utilized to elucidate individual and cultural values surrounding mentorship benefits and drawbacks.

U5. Relevant Information

All stakeholder groups were involved in survey and semi-structured interview development process to ensure that the information gathered served stakeholder needs.

U6. Meaningful Processes and Products The use of semi-structured interviews gave participants flexibility to discuss and update their understanding of the mentorship process.

U7. Timely and Appropriate Communicating and Reporting

Groups of mentors and mentees met semi-annually to discuss strategies to improve efficacy of the mentorship networks. Good ideas in any group were scaled and challenges were addressed at either individual or system levels. 
U8. Concern for Consequences and Influence

Feasibility Standards

F1. Project Management*

F2. Practical Procedures

F3. Contextual Viability

F4. Resource Use

Propriety Standards

P1. Responsive and Inclusive Orientation

P2. Formal Agreements

P3. Human Rights and Respect

P4. Clarity and Fairness

P5. Transparency and Disclosure

P6. Conflicts of Interest

P7. Fiscal Responsibility

Accuracy Standards

A1. Justified Conclusions and Decisions

A2. Valid Information

A3. Reliable Information

A4. Explicit Program and Context Descriptions

A5. Information Management
The use of surveys and semi-structured interviews allowed for identification of unanticipated outcomes and/or biases.

No specific project management strategies were employed during the mentorship network deployment and evaluation.

Stakeholder groups identified surveys and semi-structured interviews as practical and effective methods of program evaluation.

Evaluation data was collected from various stakeholder groups (mentors, mentees and cost data from administration) to balance the interests and needs of each group.

Mentorship networks had little difficulty recruiting mentors and mentees, and program costs were reasonable.

All stakeholder groups were represented in evaluation data.

Evaluation information was conveyed to stakeholders in the form of informed consent for participation in the mentorship networks and evaluation processes.

Ethics approval was obtained prior to deployment of mentorship network evaluation tools.

Involvement of all stakeholder groups in evaluation development ensured that evaluations were understandable and fair.

Mentors and mentees were updated on mentorship network progress during semiannual meetings within each stakeholder group.

The roles of all evaluators, as well as confidentiality of individual survey data was explicitly stated as part of the informed consent process.

Costs for the mentorship networks were tracked on the individual and organizational level.

Mentor and mentee groups were involved in making modifications to the mentorship network program based on survey and interview results.

Data collected in surveys and semi-structured interviews revealed gender trends and other important issues used to improve the mentorship networks.

There was consistency between surveys and interviews at different time points, improving reliability. Comparisons between time points only utilized respondents with data for both time points, to improve reliability.

Network mentorship context and design was documented explicitly prior to ethics approval.

Surveys were conducted electronically, and were stored securely. Semi-structured interview data was collected, reviewed and stored systematically and consistently. 


\begin{tabular}{|l|l|}
\hline A6. Sound Designs and Analysis & $\begin{array}{l}\text { Mixed methods were utilized for analysis of the data obtained from mentorship } \\
\text { networks. }\end{array}$ \\
\hline A7. Explicit Evaluation Reasoning* & $\begin{array}{l}\text { While changes were made to the mentorship networks, the reasoning behind these } \\
\text { changes were not fully and clearly documented and disseminated to stakeholders. }\end{array}$ \\
\hline A8. Communication and Reporting & Evaluation communications were disseminated to all stakeholder groups. \\
\hline Evaluation Accountability Standards & $\begin{array}{l}\text { All designs, procedures and evaluation tools were fully documented prior to ethics } \\
\text { approval. }\end{array}$ \\
\hline E1. Evaluation Documentation & Internal meta-evaluation occurred as outlined in the paper. \\
\hline E2. Internal Meta-evaluation & External meta-evaluation was not conducted for our mentorship network program. \\
\hline E3. External Meta-evaluation* &
\end{tabular}

*Identifies a potential area for improvement 